\title{
Phylogenetic characterization and biomass estimation of bacterial endosymbionts associated with invertebrates dwelling in chemosynthetic communities of hydrothermal vent and cold seep fields
}

\author{
Hiroyuki Yamamoto ${ }^{1, *}$, Katsunori Fujikura ${ }^{2}$, Akira Hiraishi $^{3}$, Kenji Kato ${ }^{4}$, Yonosuke Maki ${ }^{5}$ \\ ${ }^{1}$ Department of Microbiology, St. Marianna University School of Medicine, Sugao 2-16-1, Miyamae, Kawasaki, Kanagawa 216-8511, Japan \\ ${ }^{2}$ Marine Ecosystems Research Department, Japan Marine Science and Technology Center, Natushima 2-15, Yokosuka, Kanagawa 237-0061, Japan \\ ${ }^{3}$ Department of Ecological Engineering, Toyohashi University of Technology, Tenpaku-cho Hibarigaoka, Toyohashi, Aichi 441-8580, Japan \\ ${ }^{4}$ Department of Biological Sciences and Geosciences, Shizuoka University, Ootani 836, Shizuoka 422-8529, Japan \\ ${ }^{5}$ Laboratory of Biology, Faculty of Humanities and Social Sciences, Iwate University, Ueda 3-18-34, Morioka, Iwate 020-8550, Japan
}

\begin{abstract}
Molecular phylogenetics for endosymbiotic bacteria recovered from vestimentiferan tubeworm Lamellibrachia satsuma from Kagoshima Bay, vesicomyid clam Calyptogena laubieri from the Nankai Trough and mytilid mussel Bathymodiolus sp. from the Mariana Back-arc Basin, were examined by PCR-aided 16S rDNA cloning and sequencing, and quinone profiling. The 16SrRNA clones of the endosymbionts from the 3 organisms fall within $\gamma$-Proteobacteria and showed distinct lines of descent specific to their respective host. The 16S rRNA gene phylogeny confirms the hostendosymbiont specificity in the co-evolutionary process. Ubiquinones with 9 isoprene units (Q-9) or Q-10 were found as the major quinones in all test tissues of the host. Larger amounts of Q-8 were detectable only in those host body parts (gill or trophosome) harboring the endosymbiotic bacteria. These observations suggest that Q-8 is the major quinone of the endosymbionts. Based on the bacterial quinone concentration, the population densities of the bacteria present were estimated to be $10^{10}$ to $10^{11}$ cells g $^{-1}$ wet wt of host tissue. The quantitative determination of quinones may provide information about physiological activity of the chemosynthetic communities as well as their biomass production.
\end{abstract}

KEY WORDS: Quinone - 16S rRNA · Symbiosis - Chemosynthetic community - Mytilid mussel · Vesicomyid clam $\cdot$ Vestimentiferan tubeworm

\section{INTRODUCTION}

Symbiotic associations between chemolithotrophic bacteria and benthic invertebrates including vesicomyid clams, mytilid mussels and vestimentiferan tubeworms, are recognized as representative of the energetic system in invertebrate communities of hydrothermal vents or cold seep areas (Van Dover 2000). The 16S rRNA-based phylogeny of endosymbiotic bacteria from these benthos showed that they fall within $\gamma$-Proteobacteria, and that their lineage divides further into functional similaries with sulfur-oxidizing or methanotrophic bacteria. The association between endosymbionts and host animals

*Email: kyama@jamstec.go.jp can be highly specific. In the case of the vesicomyid clam Calyptogena spp., 1 species of host associates with a single endosymbiotic bacterium that is transmitted cytoplasmically through the eggs (Kojima et al. 1995, Peek et al. 1998, Fujiwara et al. 2000a). The thyasirid clam Maorithyas hadalis collected from the Japan Trench carries the dual symbiosis consisting of an outer symbiont and an inner symbiont of bacteriocyte (Fujiwara et al. 2001). The mussel Bathymodiolus spp. harbors thioautotrophic and/or methanotrophic endosymbionts, and their symbiotic relationship may be influenced strongly by the concentration of environmental methane and hydrogen sulfide (Distel et al. 1995, Fujiwara et al. 2000a). The 16S rRNA phylogeny analysis revealed that the vestimentiferan tubeworm endosymbionts form 2 distinct clades which are specific to 
either vent or seep habitats (Feldman et al. 1997, Di Meo et al. 2000). These endosymbiotic bacteria belong to a specific group or closely inherited linenages of $\gamma$-Proteobacteria on the 16S rRNA phylogenetic tree.

The endosymbiotic chemolithotrophic bacteria produce organic matter with hydrogen sulfide or methane as the primary energy sources, which are supplied as substrates to their host. Microscopic observations of body site showed the presence of myriad endosymbiont bacterial cells harbored within the tissue (Distel et al. 1991, Krueger \& Cavanaugh 1997, Fujiwara et al. $2000 b)$. The growth of the host obviously depends on the growth of symbiotic bacteria; however, the relationship between host physiology and endosymbiont density remains obscure because of the technical difficulties in estimating the bacterial density, i.e. there are no methods for cultivation of endosymbionts, and measurement accuracy is limited by microscope resolution. One of the most promising culture-independent approaches for the determination of non-cultivated bacteria is the analysis of rRNA sequences or the determination of lipid biomarker molecules, such as the respiratory quinones and fatty acids of the cell membrane. Fatty acid biomarker analysis of mussels and gastropods dwelling in deep-sea hydrothermal vents has revealed a nutritional dependency on their symbiotic bacteria (Pranal et al. 1996, 1997, Pond et al. 1998).

Isoprenoid quinones are lipid molecules that are present in all organisms driving respiratory and photosynthetic energy metabolism, where quinones play important roles in electron transport coupled to proton translocation. Since quinones of microorganisms exhibit great structural variations depending upon taxa, they have been used as good measures for studying microbial taxonomy and phylogeny (Hiraishi 1999). Microbial quinones are categorized into 2 major structural classes, the benzoquinone represented by ubiquinones (formerly coenzyme Q) and the naphthoquinone represented by menaquinones (formerly vitamin K2). The quinone profiling method, which is a form of direct chemical analysis for detecting various structural types of respiratory and photosynthetic quinones extractable from environmental samples (Iwasaki \& Hiraishi 1998), is employed for estimating microbial redox states (Hedrick \& White 1986), community structures (Hiraishi et al.
1998, 1999, Hiraishi \& Kato 1999) and their microbial biomass (Hiraishi et al. 1998, Hiraishi 1999) in the environment.

In this study, we determined 16S rRNA gene phylogeny for endosymbiotic bacteria of vesicomyid clams, mytilid mussels and vestimentiferan tubeworms. The size of the population of endosymbiotic bacteria was estimated using quantitative and qualitative determination of the quinone content of the invertebrate body parts, gill, foot and trophosome.

\section{MATERIALS AND METHODS}

Sample collection sites and specimens. The sample collection sites are shown in Fig. 1 and Table 1. After the samples had been brought aboard the support vessel, the tissue of the hosts was dissected and fixed in $70 \%(\mathrm{v} / \mathrm{v})$ ethanol for DNA analysis. The whole body was stored frozen $\left(-20\right.$ or $\left.-80^{\circ} \mathrm{C}\right)$ until quinone analysis.

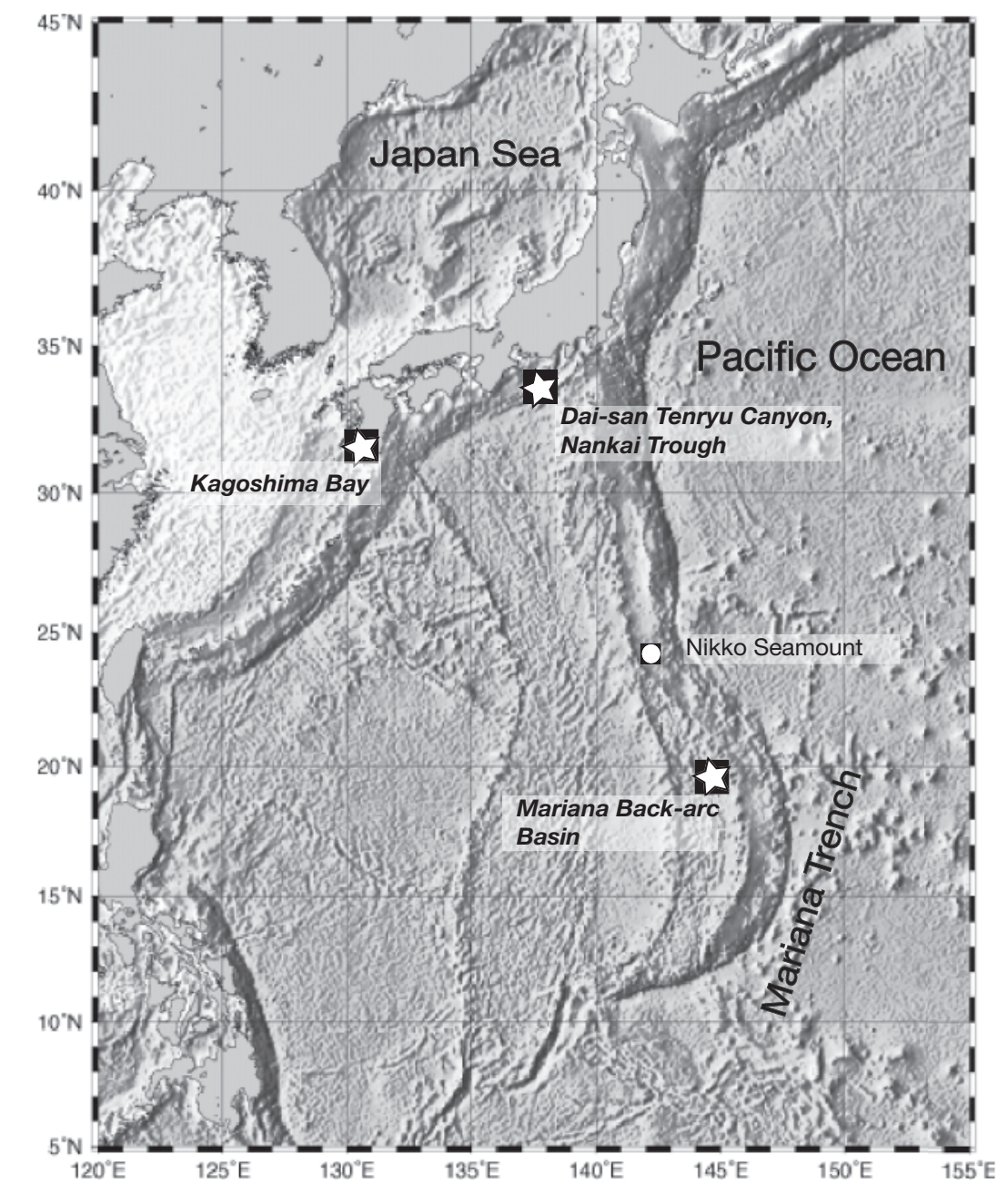

Fig. 1. Geographic locations of the chemoautotrophic community. Asterisks indicate the sample collection sites as shown in Table 1 
<smiles>CC/C=C/CC1=C(C)C(=O)c2ccccc2C1=O</smiles><smiles>C=C/C=C/CC1=C(C)C(=O)C(OC)=C(OC)C1=O</smiles><smiles>CCCCC1(C)C(=O)C(=O)C(N)=C(OC)C1=O</smiles>

Fig. 2. Chemical structures of naturally occurring isoprenoid quinones. Ubiquinones $(\mathrm{Q})$ and menaquinones $(\mathrm{MK})$ are commonly found in bacterial cells. Rhodoquinones (RQ) are derivatives of ubiquinones and occur in limited species of prokaryotes and eukaryotes. The number (n) of isoprene units in the side chain is variable depending on the taxon

DNA preparation and sequencing. The specimens (ca. $0.1 \mathrm{~g}$ wet wt) of tissue were stored in $70 \%(\mathrm{v} / \mathrm{v})$ ethanol, then washed twice with TE buffer $(10 \mathrm{mM}$ Tris- $\left.\mathrm{HCl}_{1} 1 \mathrm{mM} \mathrm{Na} \mathrm{EDTA}_{2} \mathrm{pH} 7.8\right)$, resuspended in TE buffer containing Proteinase $\mathrm{K}\left(100 \mu \mathrm{g} \mathrm{ml}^{-1}\right)$, and incubated at $55^{\circ} \mathrm{C}$ for $60 \mathrm{~min}$. A portion of the lysate was used for PCR amplification. PCR was performed with a commercial Taq polymerase kit and a pair set of universal primers for 16S rDNA sequences: forward, 5'-AGA GTT TGA TCA TGG CTC-3' (S-D-Bact-0027a-S-18); and reverse, 5'-CTA GCG ATT CCG ACT TCA-3' (S-D-Bact-1327-a-A-18) (Yamamoto et al. 1998). The numbers refer to positions in the Escherichia coli 16S rRNA. The thermal conditions were as follows: denaturation at $95^{\circ} \mathrm{C}$ for $15 \mathrm{~s}$, primer anneal- ing at $50^{\circ} \mathrm{C}$ for $60 \mathrm{~s}$ and extension at $70^{\circ} \mathrm{C}$ for $60 \mathrm{~s}$, for 40 cycles in a thermal cycler (Perkin-Elmer ABI). Amplified DNAs were purified by the spin column method using S-400 MicroSpin columns (Pharmacia Biotech). The purified DNAs were cloned directly by the TA-cloning method using a pGEM-T Vector kit (Promega) and a DNA ligation kit version 2 (Takara Shuzo). Clone libraries were constructed by transformation of E. coli JM109 (= XL1 blue strain). DNA was sequenced by linear PCR sequencing using either a DYEnamic direct sequencing kit (Amersham Pharmacia Biotech) or a DyeTerminator cycle sequencing kit (Perkin-Elmer ABI), and analyzed with a Perkin Elmer ABI 373A DNA sequencer.

Phylogenetic analysis. The sequence data for the 16S rRNA gene were examined for sequence homology employing the BLAST search program (Altschul et al. 1997) in the DNA Data Bank of Japan (DDBJ). Possible chimera artifacts of the sequences were determined by the CHECK CHIMERA program of the Ribosomal Database Project (RDP) server (Maidak et al. 2001). Other sequences used for comparisons of phylogenetic position were obtained from the RDP or DDBJ servers. Multiple alignments of sequences, calculations of nucleotide substitution rates using Kimura's 2 parameters model (Kimura 1981) and construction of a phylgoenetic tree were performed using the CLUSTAL X program (Thompson et al. 1997) and MacClade 4.0 program (Sinauer Associates). The phylogenetic tree was illustrated using the TreeView drawing program (Page 1996).

Analysis of quinones. Washed samples (ca. 1 to $5 \mathrm{~g}$ wet wt) were resuspended in $50 \mathrm{mM}$ phosphate buffer (pH 7.0) containing $1 \mathrm{mM}$ ferricyanide. Each suspension was mixed with $2.5 \mathrm{vol}$ of a chloroform/methanol mixture $(2: 1, \mathrm{v} / \mathrm{v})$, homogenized for $1 \mathrm{~min}$ and centrifuged at $5000 \times g$ for $10 \mathrm{~min}$. The resulting upper aqueous layer was discarded and the lipid layer was collected with a pipette. The residue was extracted once with acetone and then twice (30 min each) with the chloroform-methanol mixture. All extracts were combined, evaporated under vacuum and re-extracted

Table 1. Sample collection sites

\begin{tabular}{|c|c|c|c|c|c|c|c|c|}
\hline Species & Field & $\begin{array}{l}\text { Latitude } \\
\text { (N) }\end{array}$ & $\begin{array}{l}\text { Longitude } \\
\text { (E) }\end{array}$ & $\begin{array}{l}\text { Depth } \\
(\mathrm{m})\end{array}$ & Gear & $\begin{array}{l}\text { Dive } \\
\text { no. }\end{array}$ & Date & Remarks \\
\hline $\begin{array}{l}\text { Calyptogena } \\
\text { laubieri }\end{array}$ & $\begin{array}{l}\text { Dai-san Tenryu } \\
\text { Canyon, Nankai } \\
\text { Trough }\end{array}$ & $33^{\circ} 38.8^{\prime}$ & $137^{\circ} 54.7^{\prime}$ & 3750 & 'Kaiko' & 45 & 7 Aug 97 & $\begin{array}{l}\text { Cold seep } \\
\text { community }\end{array}$ \\
\hline $\begin{array}{l}\text { Bathymodiolus } \\
\text { sp. }\end{array}$ & $\begin{array}{l}\text { Mariana Back-arc } \\
\text { Basin }\end{array}$ & $18^{\circ} 12.8^{\prime}$ & $144^{\circ} 42.5^{\prime}$ & 3590 & 'Shinkai 6500' & 355 & 23 Dec 96 & $\begin{array}{l}\text { Hydrothermal } \\
\text { vent community }\end{array}$ \\
\hline $\begin{array}{l}\text { Lamellibrachia } \\
\text { satsuma }\end{array}$ & Kagoshima Bay & $31^{\circ} 39.6^{\prime}$ & $130^{\circ} 48.2^{\prime}$ & 90 & ‘Dolphin-3K' & 342 & 2 Sep 97 & $\begin{array}{l}\text { Hydrothermal } \\
\text { vent community }\end{array}$ \\
\hline
\end{tabular}


3 times with $n$-hexane/1\% saline $(1: 1, \mathrm{v} / \mathrm{v})$. The hexane extract was concentrated and then applied to a chromatography column with Sep-Pak Vac cartridges (Waters) to separate the menaquinone (MK) and ubiquinone $(\mathrm{Q})$ fractions. The quinone components (Fig. 2) were separated and identified by reversephase high-performance liquid chromatography (HPLC) using a Shimadzu model LC-10 liquid chromatograph equipped with a photodiode array detector, and mass spectrometry was used to confirm the chemical structures of HPLC-purified quinones as previously described (Hiraishi et al. 1996). The specificity of the bacterial quinone profile was examined using the Quinone Data Base of the WFCC-MIRCEN World Data Centre for Microorganisms (http://wdcm.nig.ac.jp/).

Endosymbiont biomass based on quinone content. A previous study indicated that $1 \mathrm{nmol}$ of quinones corresponded to 1.3 to $3.0 \times 10^{9}$ bacterial cells (Hiraishi et al. 1998, Hiraishi 1999). These correlation factors converted from the result of natural and synthetic sewage activated sludge were used tentatively to estimate the endosymbiont biomass in this study.

\section{RESULTS}

\section{Phylogenetic analysis}

Invertebrates collected from the deep-sea floor were identified as Lamellibrachia satsuma from Kagoshima Bay, Calyptogena laubieri from the Nankai Trough and Bathymodiolus sp. from the Mariana Back-arc Basin.

Each of 5 clones derived from the body parts of these benthic invertebrates were sequenced. An identical sequence among the 5 clones was only found in a bacterial DNA library of gill or trophosome specimens, while the sequences of clones from other body parts consisted of various and different clones. A representative clone was chosen from 5 clones of each specimen of trophosome from the vestimentiferan tube worm Lamellibrachia satsuma, gill from the vesicomyid clam Calyptogena laubieri and gill from the mytilid mussel Bathymodiolus sp., and sequenced for a nucleotide stretch from nucleotide position 8 to 1345 of the 16S rRNA gene.

The 3 representative 16S rDNA clones fall within $\gamma$-Proteobacteria and formed their respective clusters with the previously known endosymbiotic bacteria. However, the sequences of these clones were not matched with any of those available from the databases (Fig. 3). The clone (TUBE 163, AB073120) from the trophosome of vestimentiferan tube warm was related most closely to the vestimentiferan endosymbionts of the Nikko Seamount (AF165907; Di Meo et al. 2000) at a similarity level of $97 \%$. The clone (CAL 1213, AB073121) from a gill of vesicomyid clam showed 97 and $98 \%$ similarities to the endosymbionts of Calyptogena kilmeri (AF035720; Peek et al. 1998) and Vesicomya gigas (AF035726; Peek et al. 1998), respectively. The clone (BATH 35, AB073122) from a gill of mytilid mussel was related most closely to the endosymbionts of Bathymodilolus septemdierum (AB036709; Fujiwara et al. 2000b) at a similarity level of $97 \%$.

\section{Quinone analysis}

The quinone analysis revealed that Q-9 was detected as the major component from all test tissues of Lamellibrachia satsuma, and Q-10 from those of Calyptogena laubieri and Bathymodiolus (Table 2), suggesting that Q-9 or Q-10 is the major quinone of these hosts themselves. Interestingly, small amounts of RQ-9-like quinone were also detected in all tissues of L. satsuma. The trophosome, the endosymbiotic bacteria-rich organ, produced large amounts of Q-8 and much lower but significant amounts of MK-8, both of which were probably derived from the endosymbionts. Moreover, the presence of Q-8 as the major component in the gill is also thought to originate from the endosymbiotic bacteria.

The endosymbiont biomass within the host tissue was estimated based on the total concentration of the quinone components of possibly bacterial origin. The endosymbiont cell densities tentatively estimated were at an order of magnitude of $10^{10}$ to $10^{11}$ cells g ${ }^{-1}$ wet wt tissue (Table 2). The biomass of the Bathymodiolus endosymbiont was lower than that in Calyptogena laubieri and Lamellibrachia satsuma.

\section{DISCUSSION}

As reported herein, the 3 16S rRNA gene clones of endosymbiotic bacteria obtained from the benthic invertebrates of chemosynthesis-based communities, Lamellibrachia satsuma from Kagoshima Bay, Calyptogena laubieri from the Nankai Trough, and Bathymodiolus sp. from the Mariana Back-arc Basin, belong to a lineage of thioautotrophic group within $\gamma$-Proteobacteria. These endosymbionts are independent phylotypes within this phylogenetic group; however, they are closely related to the previously described endosymbionts of chemosynthesis-based communities. The endosymbiont clones from C. laubieri and Bathymodiolus sp. belong to a clade of inherited endosymbiont phylotypes of the thioautotrophs, whereas the endosymbiont clone from $L$. satsuma closely relates to the endosymbiont phylotype of the vestimentiferan tube- 


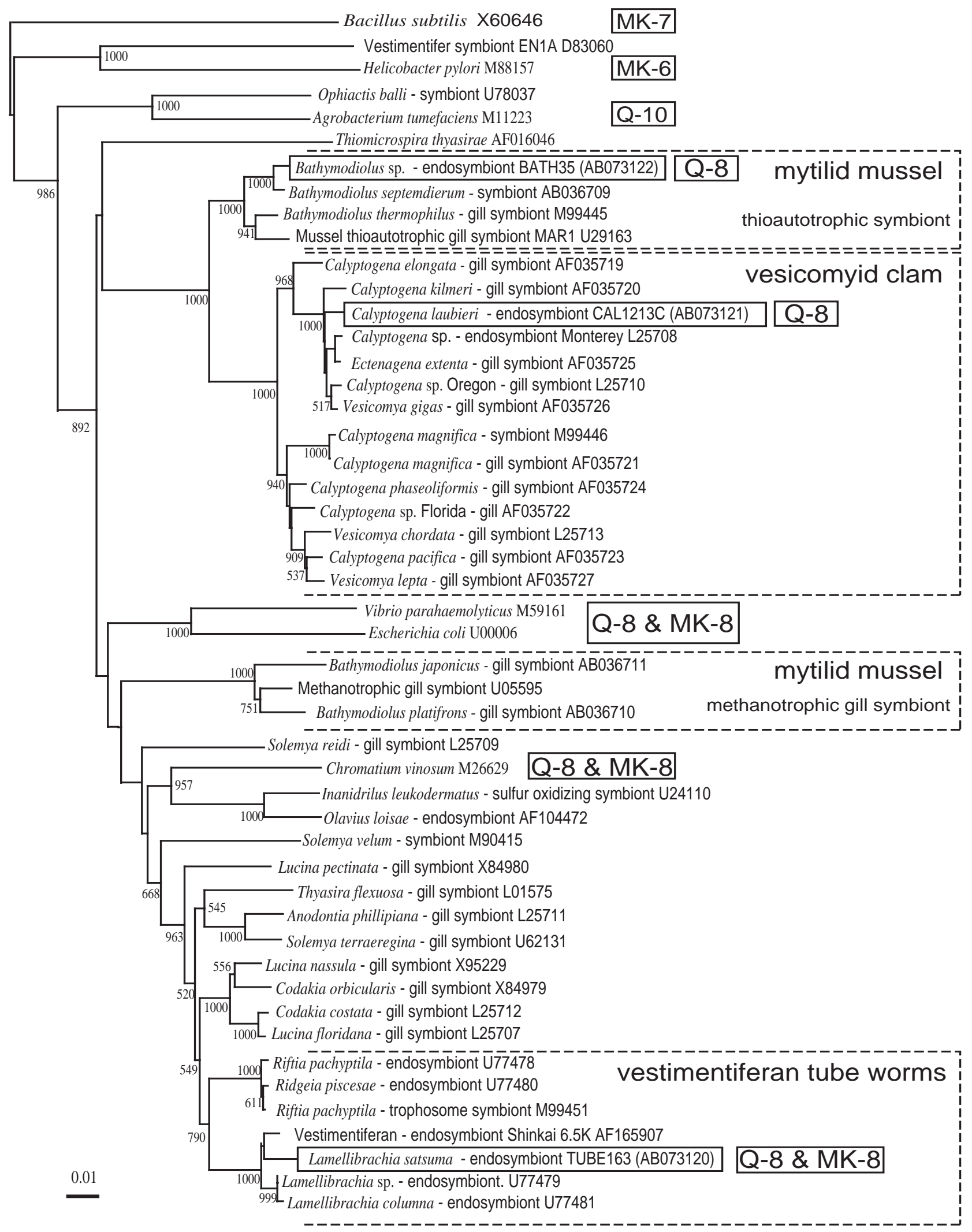

Fig. 3. Phylogenetic tree of endosymbionts and related bacterial species with structural classes of major quinones. Accession numbers of sequences are indicated after organisms name. Number of each branch is the result of 1000 bootstrap examinations and values $>500$ are indicated 
Table 2. Quinone compositions of benthic invertebrates and their endosymbiont cell density. Q: ubiquinones; MK: menaquinones; RQ: rhodoquinones; numbers: number of isoprene units in the side chain of quinone ring; t: trace $(<1$ nmol). Quinone contents assumed to originate from endosymbionts are underlined

\begin{tabular}{|c|c|c|c|c|c|c|c|}
\hline \multirow[t]{2}{*}{ Specimens } & \multicolumn{6}{|c|}{ Quinone content ( $\mathrm{nmol} \mathrm{g}^{-1}$ of tissue) } & \multirow{2}{*}{$\begin{array}{l}\text { Endosymbiont density } \\
\quad\left(\text { cell } \times 10^{11} \mathrm{~g}^{-1}\right)\end{array}$} \\
\hline & Q-7 & Q-8 & Q-9 & Q-10 & MK-8 & RQ-9 $9^{\mathrm{a}}$ & \\
\hline \multicolumn{8}{|c|}{ Lamellibrachia satsuma from Kagoshima Bay } \\
\hline Vest & $\mathrm{t}$ & $\mathrm{t}$ & 13.4 & 0 & 0 & $\mathrm{t}$ & \\
\hline Lamellae (gill) & $\mathrm{t}$ & 1.32 & 12.5 & 0 & 0 & $\mathrm{t}$ & \\
\hline Trophosome (top) & $\underline{4.26}$ & $\underline{102}$ & 35.3 & 0 & $\underline{12.4}$ & 1.65 & $1.5-3.6$ \\
\hline Trophosome (bottom) & $\underline{3.95}$ & $\underline{103}$ & 27.4 & 0 & $\underline{16.9}$ & 1.45 & $1.6-3.7$ \\
\hline \multicolumn{8}{|c|}{ Calyptogena laubieri from Nankai Trough } \\
\hline Ctenidia (gill) & $\underline{1.76}$ & $\underline{108}$ & 10.4 & 18.8 & 0 & 0 & $1.4-3.3$ \\
\hline Mantle & $\mathrm{t}$ & 1.80 & $\mathrm{t}$ & 9.67 & 0 & 0 & \\
\hline Foot & $\mathrm{t}$ & $\mathrm{t}$ & $\mathrm{t}$ & 16.3 & 0 & 0 & \\
\hline \multicolumn{8}{|c|}{ Bathymodiolus sp. from Mariana Back-arc Basin } \\
\hline Ctenidia (gill) & 1.07 & $\underline{66.9}$ & $\mathrm{t}$ & 31.7 & 0 & 0 & $0.8-2.0$ \\
\hline Mantle & $\overline{0}$ & $\overline{0}$ & 0 & 3.10 & 0 & 0 & \\
\hline Foot & $\mathrm{t}$ & $\mathrm{t}$ & $\mathrm{t}$ & 9.80 & 0 & 0 & \\
\hline
\end{tabular}

worm from the Nikko seamount $\left(23^{\circ} 5^{\prime} \mathrm{N}, 142^{\circ} 20^{\prime} \mathrm{E}\right.$; Di Meo et al. 2000), and both belong to the same phylogenetic lineage as the sedimented seep group classified by Feldman et al. (1997). However, the Nikko seamount is a hydrothermal vent field and L. satsuma is a member of the hydrothermal vent community in Kagoshima Bay. The mitochondrial gene phylogeny has shown that both of the vestimentiferan tube worms from the Nikko seamount and Kagoshima Bay are identical species (Kojima et al. 2000).

These benthic invertebrates acquire their endosymbionts by different mechanisms. The vesicomyd clams Calyptogena spp. pass the endosymbiotic bacterium vertically from parent to primary oocytes within the ovarian. The vestimentiferan tubeworms acquire the endosymbionts directly from an environmental population of the free-living form. In spite of horizontal transmission of endosymbionts, host-symbiont fidelity is also found. As shown in the phylogenetic tree, Riftia, Ridgeia and Lamellibrachia tubeworms possess the specific endosymbionts belonging to different branches.

The quinone profiling has shown that the major quinones of the endosymbionts and their hosts are distinguishable from each other, and that the bacterial clones detected correspond to the endosymbionts inhabiting the specific body parts of the benthic hosts. Q-8, detected in the gill and trophosome, is a typical quinone species of bacteria belonging to $\beta$ - and $\gamma$-Proteobacteria (Hiraishi 1999). Some species of $\gamma$-Proteobacteria, e.g. enteric bacteria, contain MK-8 in addition to Q-8, which is the case for Lamellibrachia satsuma trophosome. The features of quinone composition of the endosymbionts are similar to the quinone systems of their phylogenetic neighbors appearing on the 16S rRNA tree (Fig. 3).

The quinone biomarkers have sufficient resolution to discriminate the phylogenetic clade and bacterial taxon in a range of the genus to order, and also considerable potential to estimate the bacterial population or biomass. The quantitative determination of quinone profiles suggested dense bacterial biomass within the bacteriocyte of gills and trophosomes. The amount of quinone was related empirically to bacterial cell number, as well as the phospholipid-linked fatty acids of the bacterial membrane. The relationships between the endosymbiont biomass and the neutral to polar lipids ratio in gills of vent mussels have been reported (Pranal et al. 1996, 1997). Their estimates $\left(10^{11}\right.$ bacterial cell $\mathrm{g}^{-1}$ dry wt tissue) for mussels using endosymbiont lipids (Pranal et al. 1997) correspond well with the biomass value calculated from the quinone concentration we determined, in spite of the different criteria for convergent factors that have been employed. These preliminary estimates suggest that quantitative and qualitative determinations of lipid biomarkers such as fatty acids and quinines components will provide valuable information about the physiological states of endosymbionts. The biomass of endosymbionts probably strongly reflects the physiological robustness of the hosts dwelling in chemosynthesis-based communities in deep-sea environments. To confirm the hypothesis of a relation between biomarker quantity and physiological state, the samples from chemosynthesis-based communities in various conditions should be examined.

The determination of biomass and physiological state would make a significant contribution toward 
understanding the trophic ecology of chemosynthesisbased communities. However, no chemolithotrophic endosymbionts have been cultured to date, and the estimation of bacterial cell density relies on microscopic enumeration of cells, which is difficult because of visible disturbance by the density of the packed bacterial cells within the bacteriocyte of the host. The lipid biomarker measurements, as well as development of a new counting method for endosymbiotic cells, will improve our ability to study deep-sea chemosynthesisbased communities.

Acknowledgements. We thank the operational teams of the 'Dolphin 3K', 'Shinkai 6500' and 'Kaiko', and the captain and the crew of the supporting RVs 'Natsushima', 'Yokosuka' and 'Kairei'. We also thank Dr. J. Hashimoto of JAMSTEC for his kind help with sample collection.

\section{LITERATURE CITED}

Altschul SF, Madden TL, Schaffer AA, Zhang J, Zhang Z, Miller W, Lipman DJ (1997) Gapped BLAST and PSIBLAST: a new generation of protein database search programs. Nucleic Acids Res 25:3389-3402

Di Meo CA, Wilbur AE, Holben WE, Feldman RA, Vrijenhoek RC, Cary SC (2000) Genetic variation among endosymbionts of widely distributed vestimentiferan tubeworms. Appl Environ Microbiol 66:651-658

Distel DL, DeLong EF, Waterbury JB (1991) Pylogenetic characterization and in situ localization of the bacterial symbiont of shipworms (Terdidae: bivalvia) by using $16 \mathrm{~S}$ rRNA sequence analysis and oligodeoxynucleotide probe hybridization. Appl Environ Microbiol 57:2376-2382

Distel DL, Lee HK, Cavanaugh CM (1995) Intracellular coexistence of methano- and thioautotrophic bacteria in a hydrothermal vent mussel. Proc Natl Acad Sci USA 92:9598-9602

Feldman RA, Black MB, Cary CS, Lutz RA, Vrijenhoek RC (1997) Molecular phylogenetics of bacterial endosymbionts and their vestimentiferan hosts. Mol Mar Biol Biotechnol 6:268-277

Fujiwara Y, Kojima S, Mizota C, Maki Y, Fujikura K (2000a) Phylogenetic characterization of the endosymbionts of the deepest-living vesicomyid clam, Calyptogena fassajaponica, from the Japan Trench. VENUS 59:307-316

Fujiwara Y, Takai K, Uematsu K, Tsuchida S, Hunt JC, Hashimoto J (2000b) Phylogenetic characterization of endosymbionts in three hydrothermal vent mussels: influence on host distribution. Mar Ecol Prog Ser 208:147-155

Fujiwara Y, Kato C, Masui N, Fujikura K, Kojima S (2001) Dual symbiosis in the cold-seep thyasirid clam Maorithyas hadalis from the hadal zone in the Japan Trench, western Pacific. Mar Ecol Prog Ser 214:151-159

Hedrick DB, White DC (1986) Microbial respiratory quinones in the environment. I. A sensitive liquid chromatographic method. J Microbiol Methods 5:243-254

Hiraishi A (1999) Isoprenoid quinones as biomarkers of microbial populations in the environment. J Biosci Bioeng 88: 449-460

Hiraishi A, Kato K (1999) Quinone profiles in lake sediments: implications for microbial diversity and community structures. J Gen Appl Microbiol 45:221-227

Editorial responsibility: Otto Kinne (Editor), Oldendorf/Luhe, Germany
Hiraishi A, Ueda Y, Ishihara J, Mori T (1996) Comparative lipoquinone analysis of influent sewage and activated sludge by high-performance liquid chromatography and photodiode array detection. J Gen Appl Microbiol 42: 457-469

Hiraishi A, Ueda Y, Ishihara J (1998) Quinone profiling of bacterial communities in natural and synthetic sewage activated sludge for enhanced phosphate removal. Appl Environ Microbiol 64:992-998

Hiraishi A, Umezawa T, Yamamoto H, Kato K, Maki Y (1999) Changes in quinone profiles of hot spring microbial mats with a thermal gradient. Appl Environ Microbiol 65: 198-205

Iwasaki M, Hiraishi A (1998) A new approach to numerical analyses of microbial quinone profiles in the environments. Microbes Environ 13:67-76

Kimura M (1981) Estimation of evolutionary distances between homologous nucleotid sequences. Proc Natl Acad Sci USA 78:454-458

Kojima S, Segawa R, Kobayashi T, Hashimoto T, Fujikura K, Hashimoto J, Ohta S (1995) Phylogenetic relationships among species of Calyptogena (Bibalvia: Vesicomyidae) collected around Japan revealed by nucleotide sequences of mitochondrial genes. Mar Biol 122:401-407

Kojima S, Ohta S, Miura T, Fujiwara Y, Hashimoto J (2000) Molecular phylogenetic study of chemoautosynthesis based communities in the Manus Basin. JAMASTEC J Deep Sea Res 16:7-13

Krueger DM, Cavanaugh CM (1997) Phylogenetic diversity of bacterial symbionts of Solemya hosts based on comparative sequence analysis of 16S rRNA genes. Appl Environ Microbiol 63:91-98

Maidak BL, Cole JR, Lilburn TG, Parker CT Jr and 6 others (2001) The RDP-II (Ribosomal Database Project). Nucleic Acids Res 29:173-174

Page RDM (1996) TREEVIEW: an application to display phylogenetic trees on personal computers. Comput Appl Biosci 12:357-358

Peek AS, Feldman RA, Lutz RA, Vrijenhoek RC (1998) Cospeciation of chemoautotrophic bacteria and deep sea clams. Proc Natl Acad Sci USA 95:9962-9966

Pond DW, Bell MV, Dixon DR, Fallick AE, Segonzac M, Sargent J (1998) Stable-carbon-isotope composition of fatty acids in hydrothermal vent mussels containing methanotrophic and thiotrophic bacterial endosymbionts. Appl Environ Microbiol 64:370-375

Pranal V, Fiala-Médioni A, Guezennec J (1996) Fatty acid characteristics in two symbiont-bearing mussels from deep-sea hydrothermal vents of the West Pacific. Mar Ecol Prog Ser 142:175-184

Pranal V, Fiala-Médioni A, Guezennec J (1997) Fatty acid characteristics in two symbiont-bearing mussels from deep-sea hydrothermal vents of the south western Pacific. J Mar Biol Assoc UK 77:473-492

Thompson JD, Gibson TJ, Plewniak F, Jeanmougin F, Higgins DG (1997) The ClustalX windows interface: flexible strategies for multiple sequence alignment aided by quality analysis tools. Nucleic Acids Res 24:4876-4882

Van Dover CL (2000) The ecology of deep-sea hydrothermal vents. Princeton University Press, Princeton, NJ

Yamamoto H, Hiraishi A, Kato K, Chiura HX, Maki Y, Shimizu A (1998) Phylogenetic evidence for the existence of novel thermophilic bacteria in hot spring sulfurturf microbial mats in Japan. Appl Environ Microbiol 64: $1680-1687$

Submitted: January 9, 2002; Accepted: September 5, 2002

Proofs received from author(s): November 13, 2002 